\title{
Synthesis, CP-MAS NMR Characterization, and Antibacterial Activities of Glycine and Histidine Complexes of $\mathrm{Cd}(\mathrm{SeCN})_{2}$ and $\mathrm{Hg}(\mathrm{SeCN})_{2}$
}

\author{
Bassem A. Al-Maythalony, ${ }^{1}$ M. Monim-ul-Mehboob, ${ }^{1}$ Mohammed I. M. Wazeer, ${ }^{1}$ \\ Anvarhusein A. Isab, ${ }^{1}$ M. Nasiruzzaman Shaikh, ${ }^{2}$ and Saleh Altuwaijri ${ }^{3}$ \\ ${ }^{1}$ Department of Chemistry, King Fahd University of Petroleum and Minerals, Dhahran 31261, Saudi Arabia \\ ${ }^{2}$ Center of Research Excellence in Nanotechnology (CENT), King Fahd University of Petroleum and Minerals, \\ Dhahran 31261, Saudi Arabia \\ ${ }^{3}$ Clinical Research Laboratory, Saad Research \& Development Center, Saad Specialist Hospital, Al-Khobar 31952, Saudi Arabia \\ Correspondence should be addressed to Anvarhusein A. Isab; aisab@kfupm.edu.sa
}

Received 18 November 2012; Revised 30 December 2012; Accepted 3 January 2013

Academic Editor: Imre Sovago

Copyright (C) 2013 Bassem A. Al-Maythalony et al. This is an open access article distributed under the Creative Commons Attribution License, which permits unrestricted use, distribution, and reproduction in any medium, provided the original work is properly cited.

\begin{abstract}
The synthesis and characterization of cadmium and mercury complexes of selenocyanate of the type $\left[(\mathrm{L}) \mathrm{M}(\mathrm{SeCN})_{2}\right]$ are described, where $\mathrm{L}$ is L-Histidine (His) or L-Glycine (Gly) and $\mathrm{M}_{\text {is }} \mathrm{Cd}^{2+}$ or $\mathrm{Hg}^{2+}$. These complexes are obtained by the reaction of 1 equivalent of respective amino acids with metal diselenocyanate precursor in a mixture of solvents (methanol $:$ water $=1: 1$ ). These synthesized compounds are characterized by analytical and various spectroscopic techniques such as elemental analysis $(\mathrm{EA})$, IR, ${ }^{1} \mathrm{H}$, and ${ }^{13} \mathrm{C}$ $\mathrm{NMR}$ in solution and in the solid state for ${ }^{13} \mathrm{C}$ and ${ }^{15} \mathrm{~N}$. The in vitro antibacterial activities of these complexes have been investigated with standard type cultures of Escherichia coli (MTCC 443), Klebsiella pneumoniae (MTCC 109), Pseudomonas aeruginosa (MTCC 1688), Salmonella typhi (MTCC 733), and Staphylococcus aureus (MTCC 737).
\end{abstract}

\section{Introduction}

Since the metal ions play vital roles in a number of biological processes such as biomolecules stabilizations, enzyme regulations, transportation of fluids through transmembrane channels, and so forth [1-3], numerous metal ions amino acids complexes also act as potent antifungal, antibacterial, and anticancer drugs [4-6]. Therefore, the extensive studies of these metallic species have been dedicated to understand the impact on living systems. It is well known that metal-binding proteins cover a large fraction of the total protein, and they are actively participating in several essential life processes $[2,3]$. Therefore, understanding of the physicochemical and biochemical properties of metals with amino acids becomes indispensible and a broad area of research for several years [7-11].
Among all amino acids found in nature, Histidine is often found as a ligand in various types of metalloenzymes because it is the key amino acids residue in many enzymatic reactions [12]. This is may be due to its stereochemical location of the coordinating atom in Histidine. The Histidine skeleton contains the imidazole side group having two nitrogen atoms capable of participating in metal-ligand coordination sphere thereby it can take on various metal-bound forms in proteins. Thus, it is important to know the coordination modes of the Histidine (His) and Glycine (Gly) ligands to understand the reaction mechanism of metalloenzymes [13].

The coordination modes of various metal ions with amino acids have been the topic of discussion for a long period of time, and the ideas to get the binding modes are not easy to predict for amino acids with large side chain such as Histidine [16], because of different types of donor atoms present in 


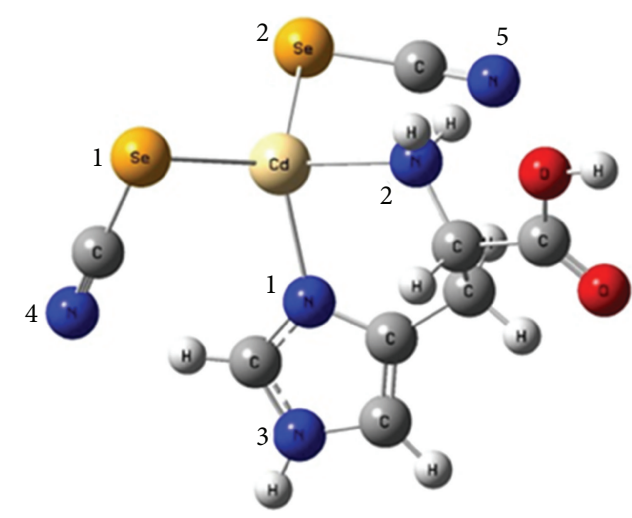

(a)

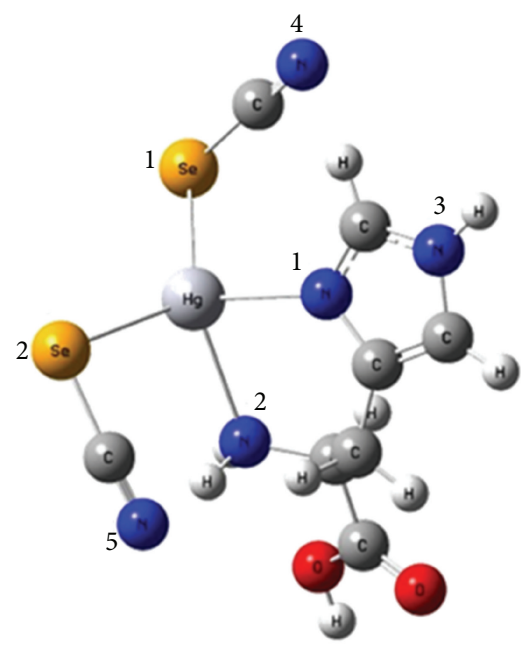

(c)

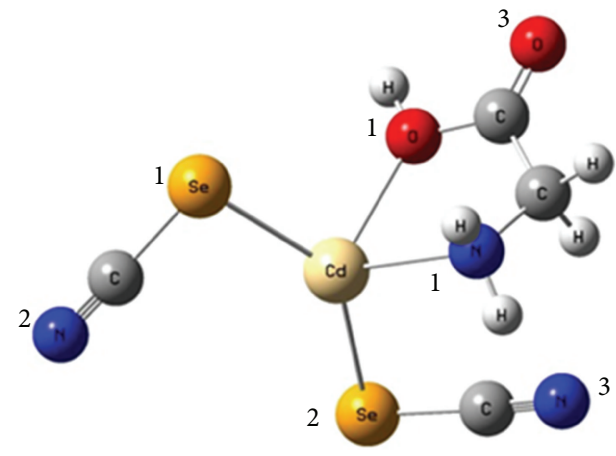

(b)

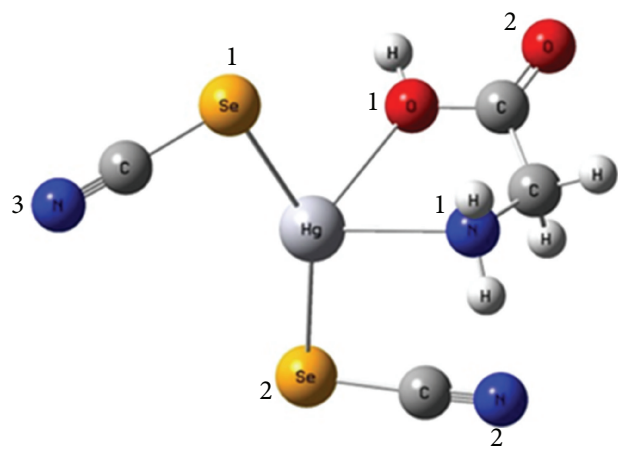

(d)

Scheme 1: Optimized geometries of $\left[\mathrm{LM}(\mathrm{SeCN})_{2}\right](\mathrm{a}),(\mathrm{b}),(\mathrm{c})$, and (d), obtained at the B3LYP/LanL2DZ level of theory using Gaussian 09, Revision A. 1. L refers to Histidine or Glycine, while M refers to Hg or Cd.

TABLE 1: Elemental analysis of the prepared complexes.

\begin{tabular}{lcccc}
\hline \multirow{2}{*}{ Complex } & M. Pt. $(\mathrm{C})$ & \multicolumn{2}{c}{ Found (Calcd.)\% } \\
& & $\mathrm{H}$ & $\mathrm{C}$ & $\mathrm{N}$ \\
\hline$(\mathrm{Gly}) \mathrm{Cd}(\mathrm{SeCN})_{2}$ & Decomp. at 184 & $1.32(1.27)$ & $12.15(12.09)$ & $10.78(10.57)$ \\
$(\mathrm{Gly}) \mathrm{Hg}(\mathrm{SeCN})_{2}$ & $>300$ & $1.10(1.04)$ & $2.04(9.89)$ & $9.00(8.65)$ \\
$(\mathrm{His}) \mathrm{Cd}(\mathrm{SeCN})_{2}$ & Decomp. $>205$ & $2.00(1.90)$ & $17.11(16.99)$ & $14.88(14.67)$ \\
$(\mathrm{His}) \mathrm{Hg}(\mathrm{SeCN})_{2}$ & Decomp. $>140$ & $1.70(1.60)$ & $12.64(12.38)$ \\
\hline
\end{tabular}

amino acid backbone. In this point it has become necessary to study its active sites and binding affinity to transition metals at both theoretical and experimental levels. In line with efforts made by theoretical studies it has appeared that the stereochemical suitability of the metal ions play a critical role in determining the location of bond formations [17].

Selenocyanate ligand can have versatile binding modes $[18,19]$; nevertheless soft Se center is expected to coordinate more preferably to soft metals leaving the harder $\mathrm{N}$ uncoordinated [20, 21].

In order to gain better understanding of the interaction of the metal ions with macromolecules involving amino acids, knowledge of the structure and the energetic of the metal ions coordination to amino acids are required. In an effort to obtain a more complete picture, we have synthesized a number of hitherto unknown cadmium and mercury 
TABLE 2: IR frequencies, $v\left(\mathrm{~cm}^{-1}\right) \mathrm{Hg}(\mathrm{SeCN})_{2}$ and $\mathrm{Cd}(\mathrm{SeCN})_{2}$ complexes theoretical versus experimental.

\begin{tabular}{|c|c|c|c|c|c|c|}
\hline Species & $v(\mathrm{C}=\mathrm{O})$ Exp. & $v(\mathrm{C}=\mathrm{O})$ Theo. & $v(\mathrm{SeCN})$ Exp. & $v(\mathrm{SeCN})$ Theo. & $v\left(\mathrm{NH}_{2}\right)$ Exp. & $v\left(\mathrm{NH}_{2}\right)$ Theo. \\
\hline $\mathrm{KSeCN}$ & - & - & $2070^{\mathrm{a}}$ & - & - & - \\
\hline L-Gly & $1606 s$ & - & - & - & 3424 & - \\
\hline L-Hist & $1634 \mathrm{~s}$ & - & - & - & 3127 & - \\
\hline $\mathrm{Cd}(\mathrm{SeCN})_{2}$ & - & - & 2107 & - & - & - \\
\hline$(\mathrm{L}-\mathrm{Gly}) \mathrm{Cd}(\mathrm{SeCN})_{2}$ & $1611 \mathrm{~s}$ & 1759 & 2107 & 2127 & 3450 & 3455 \\
\hline (L-Hist) $\mathrm{Cd}(\mathrm{SeCN})_{2}$ & $1631 \mathrm{~s}$ & 1718 & 2109 & 2112 & 3460 & 3402 \\
\hline $\mathrm{Hg}(\mathrm{SeCN})_{2}$ & - & - & 2127 & - & - & - \\
\hline$(\mathrm{L}-\mathrm{Gly}) \mathrm{Hg}(\mathrm{SeCN})_{2}$ & $1611 \mathrm{~s}$ & 1742 & 2130 & 2137 & 3447 & 3476 \\
\hline (L-Hist) $\mathrm{Hg}(\mathrm{SeCN})_{2}$ & $1636 s$ & 1716 & 2111 & 2118 & 3422 & 3423 \\
\hline
\end{tabular}
${ }^{\mathrm{a}}[14]$.

TABle 3: ${ }^{13} \mathrm{C}$ NMR chemical shifts of $\mathrm{Hg}(\mathrm{SeCN})_{2}$ and $\mathrm{Cd}(\mathrm{SeCN})_{2}$ complexes in DMSO- $d_{6}$.

\begin{tabular}{|c|c|c|c|c|c|c|c|}
\hline Species & $\mathrm{SeCN}$ & $\mathrm{C}=\mathrm{O}$ & $\mathrm{C}-1$ & $\mathrm{C}-2$ & $\mathrm{C}-3$ & C-4 & $\mathrm{C}-5$ \\
\hline His & - & 174.7 & 136.2 & 135.0 & 117.9 & 55.1 & 29.0 \\
\hline Gly & - & 173.1 & 42.5 & & & & \\
\hline $\mathrm{Cd}(\mathrm{SeCN})_{2}$ & 116.9 & & & & & & \\
\hline$(\mathrm{His}) \mathrm{Cd}(\mathrm{SeCN})_{2}$ & 115.4 & 173.0 & 136.6 & 134.5 & 117.0 & 53.5 & 28.1 \\
\hline$(\mathrm{Gly}) \mathrm{Cd}(\mathrm{SeCN})_{2}$ & 119.0 & 194.9 & & & & & \\
\hline $\mathrm{Hg}(\mathrm{SeCN})_{2}$ & 103.3 & & & & & & \\
\hline (His) $\mathrm{Hg}(\mathrm{SeCN})_{2}$ & 109.8 & 170.3 & 135.0 & 132.3 & 116.4 & 53.3 & 27.4 \\
\hline$(\mathrm{Gly}) \mathrm{Hg}(\mathrm{SeCN})_{2}$ & 116.5 & 189.2 & & & & & \\
\hline
\end{tabular}

TABLE $4:{ }^{77}$ Se NMR chemical shifts of $\mathrm{Hg}(\mathrm{SeCN})_{2}$ and $\mathrm{Cd}(\mathrm{SeCN})_{2}$ complexes in DMSO- $d_{6}$.

\begin{tabular}{lc}
\hline Species & ${ }^{77} \mathrm{Se}$ (in ppm) \\
\hline $\mathrm{Cd}(\mathrm{SeCN})_{2}$ & -272.94 \\
$\mathrm{Hg}(\mathrm{SeCN})_{2}$ & -109.18 \\
$(\mathrm{His}) \mathrm{Hg}(\mathrm{SeCN})_{2}$ & -169.71 \\
\hline
\end{tabular}

Table 5: Solid-state ${ }^{13} \mathrm{C}$ Isotropic Chemical Shifts $\left(\delta_{\text {iso }}\right)$ and Principle Shielding Tensors $\left(\sigma_{x x}\right)^{\mathrm{a}}$ of complexes Cd(II)-Selenocyanate complexes with Glycine and Histidine ligands.

\begin{tabular}{lccccccc}
\hline Complex & Nucleus & $\delta_{\text {iso }}$ & $\sigma_{11}$ & $\sigma_{22}$ & $\sigma_{33}$ & $\Delta \sigma$ & $\eta$ \\
\hline \multirow{3}{*}{$\mathrm{Cd}(\mathrm{SeCN})_{2}$} & ${ }^{113} \mathrm{Cd}$ & 211.9 & 322 & 283 & 30 & 291 & 0.73 \\
& ${ }^{77} \mathrm{Se}$ & -119.6 & 53 & 41 & -452 & 505 & 0.96 \\
& ${ }^{13} \mathrm{C}$ & 117.0 & 222 & 205 & -76 & 298 & 0.89 \\
\hline \multirow{2}{*}{$(\mathrm{Gly}) \mathrm{Cd}(\mathrm{SeCN})_{2}$} & ${ }^{13} \mathrm{C}$ & 170.8 & 242 & 171 & 98 & -109 & 0.98 \\
& ${ }^{13} \mathrm{C}$ & 119.9 & 212 & 124 & 23 & -146 & 0.90 \\
\hline & ${ }^{13} \mathrm{C}$ & 169.3 & 236 & 169 & 102 & -101 & 0.99 \\
$(\mathrm{His}) \mathrm{Cd}(\mathrm{SeCN})_{2}$ & ${ }^{13} \mathrm{C}$ & 108.4 & 181 & 103 & 41 & -101 & 0.86 \\
& ${ }^{13} \mathrm{C}$ & 132.0 & 202 & 136 & 58 & -111 & 0.90 \\
& ${ }^{13} \mathrm{C}$ & 129.2 & 196 & 130 & 61 & -102 & 0.96 \\
& ${ }^{13} \mathrm{C}$ & 119.5 & 213 & 120 & 23 & -142 & 0.97 \\
\hline
\end{tabular}

${ }^{\mathrm{a}}$ Isotropic shielding, $\sigma_{i}=\left(\sigma_{11}+\sigma_{22}+\sigma_{33}\right) / 3 ; \Delta \sigma=\sigma_{33}-0.5\left(\sigma_{11}+\sigma_{22}\right) ; \eta=$ $3\left(\sigma_{22}-\sigma_{11}\right) / 2 \Delta \sigma$.

selenocyanate complexes and their characterization using various important spectroscopic techniques.

\section{Experimental}

\subsection{General Remarks}

2.2. Preparation of $\mathrm{Cd}(\mathrm{II})$ and $\mathrm{Hg}(\mathrm{II})$ Complexes. A solution of $\mathrm{CdCl}_{2}$ in $10 \mathrm{~mL}$ dist. water was mixed with a stoichiometrically equivalent amount of ligand (Histidine or Glycine) in $10 \mathrm{~mL}$ solvent mixture (methanol: water $=1: 1$ in volume), produced solution stirred for $30 \mathrm{~min}$, then two equivalents $\mathrm{KSeCN}$ water solution was added, the resulting mixture fluxed with nitrogen gas with stirring for $15 \mathrm{~min}$ then heat it for $\sim 1.5$ hour at $70^{\circ} \mathrm{C}$. The product was filtered and dried. The same procedure was applied for mercury complexes using $\mathrm{HgCl}_{2}$ instead of $\mathrm{CdCl}_{2}$.

2.3. Spectroscopic Measurements. The measurements of solidstate IR and solution NMR were recorded as described in the literature $[22,23]$. The solution NMR chemical shifts of ligands along with corresponding complexes are given in Tables 3 and 4 .

2.4. Solid-State NMR Studies. Natural abundance ${ }^{13} \mathrm{C}$ solidstate NMR spectra were obtained on a JEOL LAMBDA 500 spectrometer operating at $110.85 \mathrm{MHz}$, corresponding to a magnetic field of $11.74 \mathrm{~T}$, at ambient temperature of $25^{\circ} \mathrm{C}$. Samples were packed into $6 \mathrm{~mm}$ zirconia rotors. Crosspolarization and high power decoupling were employed. Pulse delay of $7.0 \mathrm{~s}$ and a contact time of $5.0 \mathrm{~ms}$ were used for carbon observations in the CPMAS experiments, whereas the pulse delay of $10 \mathrm{~s}$ and a contact time of $6.0 \mathrm{~ms}$ were 
TABLE 6: Solid-state ${ }^{15} \mathrm{~N}$ isotropic chemical shifts $\left(\delta_{\text {iso }}\right)$ and principle shielding tensors $\left(\delta_{x x}\right)^{\mathrm{a}}$ of complexes, Hg(II)-selenocyanate complexes.

\begin{tabular}{lcccccc}
\hline Complex & Nucleus & $\delta_{\text {iso }}$ & $\delta_{11}$ & $\delta_{22}$ & $\delta_{33}$ & \multicolumn{1}{c}{$\eta$} \\
\hline His & ${ }^{15} \mathrm{~N}$ & -202.55 & -97.76 & -181 & -328.85 & -189.45 \\
& ${ }^{15} \mathrm{~N}$ & -331.02 & - & - & - & - \\
$(\mathrm{His}) \mathrm{Hg}(\mathrm{SeCN})_{2}$ & ${ }^{15} \mathrm{~N}$ & -156.73 & -27.66 & - & -272.80 & -174.11 \\
& ${ }^{15} \mathrm{~N}$ & -146.5 & - & 169.72 & - & - \\
Gly & ${ }^{15} \mathrm{~N}$ & -345.56 & - & - & - & - \\
$($ Gly $) \mathrm{Hg}(\mathrm{SeCN})_{2}$ & ${ }^{15} \mathrm{~N}$ & -311.01 & - & - & - \\
\hline
\end{tabular}

${ }^{\mathrm{a}}$ Isotropic shielding, $\sigma_{i}:\left(\sigma_{11}+\sigma_{22}+\sigma_{33}\right) / 3 ; \Delta \sigma: \sigma_{33}-0.5\left(\sigma_{11}+\sigma_{22}\right) ; \eta: 3\left(\sigma_{22}-\sigma_{11}\right) / 2 \Delta \sigma$.

TABLE 7: Selected bond lengths $(\AA)$ for $\left[\mathrm{LM}(\mathrm{SeCN})_{2}\right]$ for optimized structure using B3LYP/LanL2DZ; L refers to Histidine and Glycine, while $\mathrm{M}$ refers to $\mathrm{Hg}$ or $\mathrm{Cd}$.

\begin{tabular}{lclcccc}
\hline \multicolumn{2}{c}{$\mathrm{Hg}(\mathrm{SeCN})_{2}+\mathrm{His}$} & \multicolumn{2}{c}{$\mathrm{Cd}(\mathrm{SeCN})_{2}+\mathrm{His}$} & \multicolumn{2}{c}{$\mathrm{Hg}(\mathrm{SeCN})_{2}+\mathrm{Gly}$} & $\mathrm{Cd}(\mathrm{SeCN})_{2}+\mathrm{Gly}$ \\
\hline $\mathrm{Hg}-\mathrm{Se} 1$ & 2.765 & $\mathrm{Cd}-\mathrm{Se} 1$ & 2.718 & $\mathrm{Hg}-\mathrm{Se} 1$ & 2.699 & $\mathrm{Cd}-\mathrm{Se} 1$ \\
$\mathrm{Hg}-\mathrm{Se} 2$ & 2.795 & $\mathrm{Cd}-\mathrm{Se} 2$ & 2.745 & $\mathrm{Hg}-\mathrm{Se} 2$ & 2.731 & $\mathrm{Cd}-\mathrm{Se} 2$ \\
$\mathrm{Hg}-\mathrm{N} 1$ & 2.434 & $\mathrm{Cd}-\mathrm{N} 1$ & 2.302 & $\mathrm{Hg}-\mathrm{N} 1$ & 2.576 & $\mathrm{Cd}-\mathrm{N} 1$ \\
$\mathrm{Hg}-\mathrm{N} 2$ & 2.537 & $\mathrm{Cd}-\mathrm{N} 2$ & 2.399 & $\mathrm{Hg}-\mathrm{O} 1$ & 2.656 & $\mathrm{Cd}-\mathrm{O} 1$ \\
$\mathrm{C}=\mathrm{O}$ & 1.236 & $\mathrm{C}=\mathrm{O}$ & 1.236 & $\mathrm{C}=\mathrm{O}$ & 1.232 & 2.691 \\
$\mathrm{C}-\mathrm{O}$ & 1.386 & $\mathrm{C}-\mathrm{O}$ & 1.386 & $\mathrm{C}-\mathrm{O}$ & 1.402 & $\mathrm{C}=\mathrm{O}$ \\
\hline
\end{tabular}

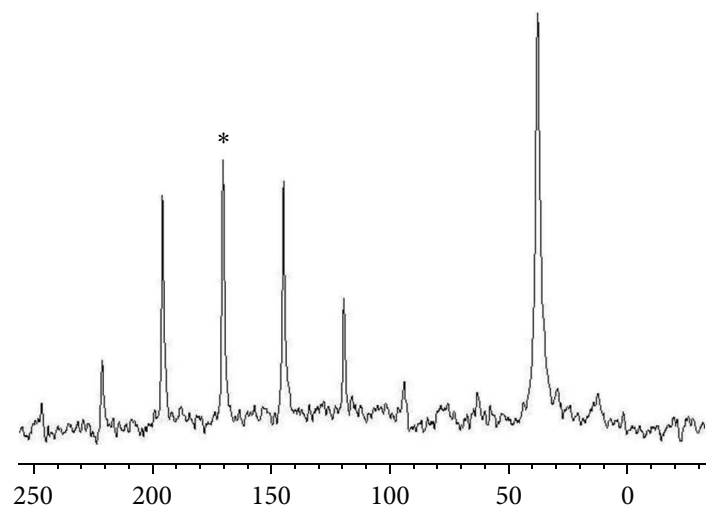

(a)

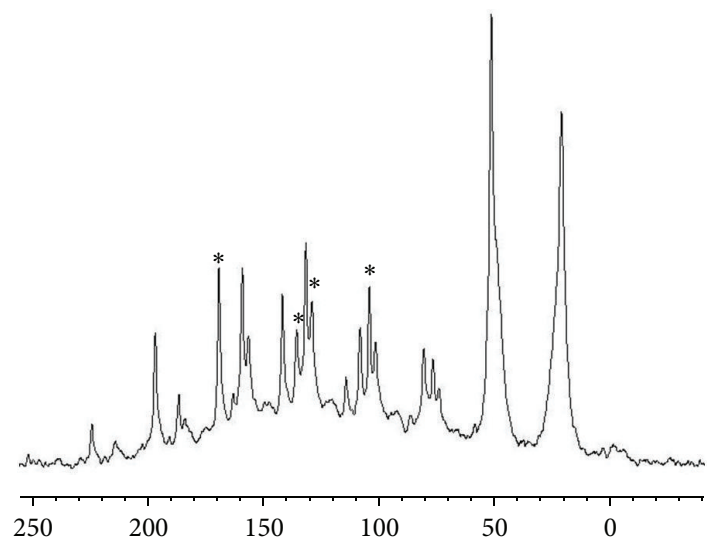

(b)

Figure 1: ${ }^{13} \mathrm{C}$ CPMAS spectra of (a) $(\mathrm{Gly}) \mathrm{Cd}(\mathrm{SeCN})_{2}$, (b) $(\mathrm{His}) \mathrm{Cd}(\mathrm{SeCN})_{2}$. The center peak is denoted by “*." used in the selenium observation. The magic angle spinning rates were from 3000 to $5000 \mathrm{~Hz} .{ }^{13} \mathrm{C}$ chemical shifts were referenced to TMS by setting the high-frequency isotropic peak of solid adamantane to $38.48 \mathrm{ppm}$.

The ${ }^{15} \mathrm{~N}$ NMR spectrum was recorded at $50.55 \mathrm{MHz}$ using ${ }^{15} \mathrm{NH}_{4} \mathrm{NO}_{3}$ as external reference, which lies at $-358.62 \mathrm{ppm}$ relative to pure $\mathrm{MeNO}_{2}$ [24]. The spectral conditions for ${ }^{15} \mathrm{~N}$ were $32 \mathrm{~K}$ data points, $0.721 \mathrm{sec}$ acquisition time, $2.50 \mathrm{sec}$ delay time, $60^{\circ}$ pulse angle, and approximately 5000 scans. The chemical shift of nitrogen was initially referenced with respect to liquid $\mathrm{NH}_{3}$, by setting the ${ }^{15} \mathrm{~N}$ peak in enriched solid ${ }^{15} \mathrm{NH}_{4} \mathrm{Cl}$ to $40.73 \mathrm{ppm}$ [25] and then converted to the standard nitromethane by a shift of $-380.0 \mathrm{ppm}$ [24] for ammonia. The ${ }^{13} \mathrm{C}$ and ${ }^{15} \mathrm{~N}$ spectra containing spinning sideband manifolds were analyzed using a computer program WSOLIDS developed at Dalhousie and Tubingen universities [26].

2.5. Computational Study. Geometry optimization was done for the built structures and optimized by DFT level of theory with LanL2DZ (Los Alamos ECP plus double zeta) [27, 28] basis sets using Gaussian 09, Revision A. 1 program package [29].

2.6. Test of Bacterial Strains. Standard type cultures of Escherichia coli (MTCC 443), Klebsiella pneumoniae (MTCC 109), Pseudomonas aeruginosa (MTCC 1688), Salmonella typhi (MTCC 733), and Staphylococcus aureus (MTCC 737) were obtained from Microbial Type Culture Collection (MTCC) Chandigarh, India). The agar well-diffusion technique [30] was used to screen the antibacterial activity. In 


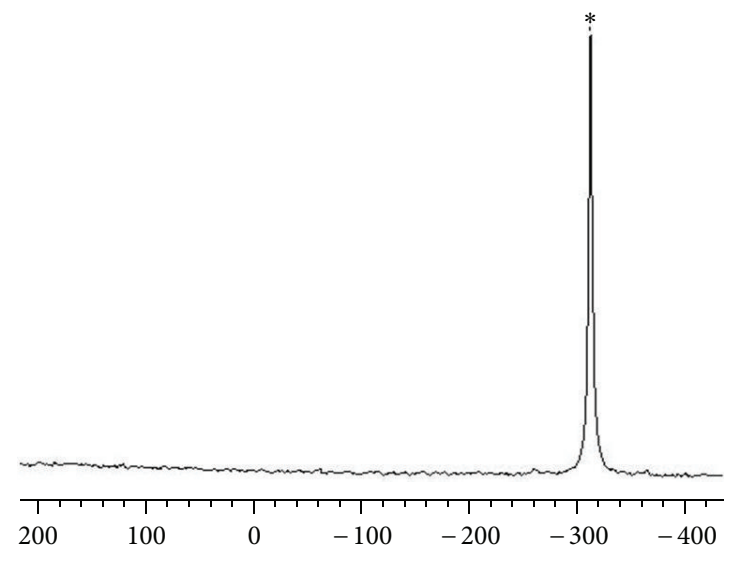

(a)

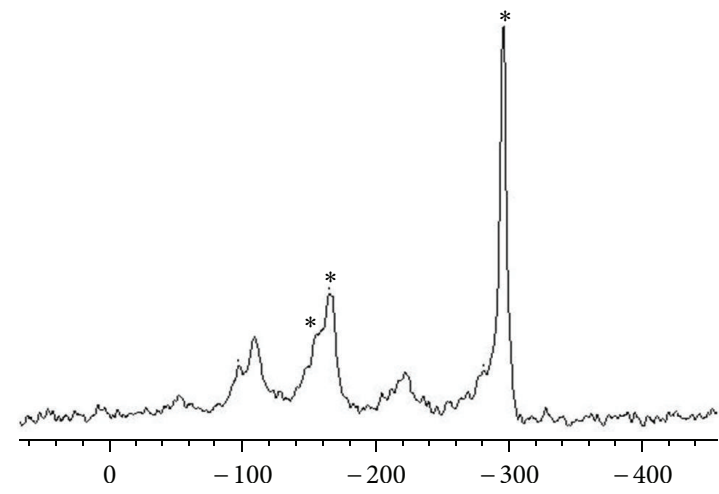

(b)

Figure $2:{ }^{15} \mathrm{~N}$ NMR spectra of (a) $(\mathrm{Gly}) \mathrm{Hg}(\mathrm{SeCN})_{2}$ and (b) (His) $\mathrm{Hg}(\mathrm{SeCN})_{2}$.<smiles></smiles><smiles></smiles><smiles>N#CC1([As])NCC(=O)O1</smiles><smiles>N#C[Si]1(C#N)NCC(=O)O1</smiles>

Figure 3: Possible binding sites for $\mathrm{Cd}^{2+}$ and $\mathrm{Hg}^{2+} \mathrm{His}$ and Gly complexes.

vitro antibacterial activities were screened by using nutrient agar plates obtained from HiMedia (Mumbai, India). The plates were prepared by pouring $20 \mathrm{~mL}$ of molten media into a sterile Petri dish and allowed to solidify for 5 minutes (Table 1). A sterile cork borer of diameter $6.0 \mathrm{~mm}$ was used to make wells in the agar plates. Inoculums were swabbed uniformly on the surface of agar plates. $0.1 \mathrm{mg} /$ well were loaded on $6.00 \mathrm{~mm}$ diameter wells. The plates were allowed to stand for $1 \mathrm{~h}$ for diffusion then incubated at $37^{\circ} \mathrm{C}$ for $24 \mathrm{hrs}$. At the end of incubation, inhibition zones were measured.

\section{Results and Discussions}

3.1. IR and NMR Studies. The ${ }^{13} \mathrm{C}$ solution NMR data of all complexes were shown in Table 3. The downfield chemical shifts were observed for the prepared complexes for $(\mathrm{Gly}) \mathrm{Cd}(\mathrm{SeCN})_{2}$ at $194.9 \mathrm{ppm}$ and $(\mathrm{Gly}) \mathrm{Hg}(\mathrm{SeCN})_{2}$ at 189.24 with respect to the free ligand, Glycine at $173.1 \mathrm{ppm}$. These high downfield shifts resulted from the electron donation from Glycine carboxylate to metal thereby causing about $20 \mathrm{ppm}$ shifts of carbonyl carbon, while this shift was not observed in the Histidine complexes because, in Histidine complexes, imidazole nitrogen and $\alpha$-amine are involved in coordination to the metal center, which agree with the reported binding mode of Histidine to mercury metal ion as shown in Figure 3 [31].

The $\mathrm{C} \equiv \mathrm{N}$ infrared frequency for $\mathrm{Hg}(\mathrm{SeCN})_{2}$ is higher than that for $\mathrm{Cd}(\mathrm{SeCN})_{2}$ which means stronger $\mathrm{C}-\mathrm{N}$ bond, and this lead to less electron density at the selenium atom that derives more back donation from the $\mathrm{Hg}$ to $\mathrm{Se}$, which makes $\mathrm{Hg}-\mathrm{Se}$ bond stronger. This less electron density observed also by downfield shift for the de-shielded Se bound to $\mathrm{Hg}$ $(-109 \mathrm{ppm})$ compared with Se bound to $\mathrm{Cd}(-272 \mathrm{ppm})$ as shown by ${ }^{77} \mathrm{Se}$ NMR (Table 4$)$. In case of Histidine complexes of $\mathrm{Hg}(\mathrm{SeCN})_{2}$ selenium atom became more shielded and shifted upfield $(-169.71 \mathrm{ppm})$ because of donation from Histidine to the metal center, which causes even stronger $\pi$-back donation to selenium. In Table 2 , the IR data shows the highest red shift for selenocyanate frequency for Histidine complex of mercury which means the highest $\pi$-back donation from the metal to the selenocyanate rather than Glycine so greater donation to the antibonding $\pi$-orbitals of the cyanate from selenium atom indication of stronger Histidine mercury bonding than the rest of the complexes 
TABLE 8: Selected torsion angle $\left(^{\circ}\right)$ for $\left[\mathrm{LM}(\mathrm{SeCN})_{2}\right]$ for optimized structure using B3LYP/LanL2DZ; L refers to Histidine and Glycine, while $\mathrm{M}$ refers to $\mathrm{Hg}$ or $\mathrm{Cd}$.

\begin{tabular}{|c|c|c|c|c|c|c|c|}
\hline \multicolumn{2}{|c|}{$\mathrm{Hg}(\mathrm{SeCN})_{2}+\mathrm{His}$} & \multicolumn{2}{|c|}{$\mathrm{Cd}(\mathrm{SeCN})_{2}+\mathrm{His}$} & \multicolumn{2}{|c|}{$\mathrm{Hg}(\mathrm{SeCN})_{2}+\mathrm{Gly}$} & \multicolumn{2}{|c|}{$\mathrm{Cd}(\mathrm{SeCN})_{2}+$ Gly } \\
\hline Sel-C-N4 & 178.79 & Se1-C-N4 & 178.45 & Se1-C-N3 & 178.03 & Se1-C-N2 & 178.20 \\
\hline Se2-C-N5 & 176.36 & Se2-C-N5 & 175.84 & $\mathrm{Se} 2-\mathrm{C}-\mathrm{N} 2$ & 177.04 & Se2-C-N3 & 176.32 \\
\hline N1-Hg-N2 & 83.87 & N1-Cd-N2 & 87.79 & N1-Hg-O1 & 64.67 & N1-Cd-O1 & 96.81 \\
\hline Sel-Hg-Se2 & 125.79 & Sel-Cd-Se2 & 121.32 & Sel-Hg-Se2 & 149.92 & Sel-Cd-Se2 & 139.71 \\
\hline Sel-Hg-N1 & 108.92 & Sel-Cd-N1 & 111.15 & Sel-Hg-N1 & 107.50 & Sel-Cd-N1 & 112.35 \\
\hline Se2-Hg-N2 & 99.18 & Se2-Cd-N2 & 101.26 & $\mathrm{Se} 2-\mathrm{Hg}-\mathrm{O} 1$ & 111.58 & Se2-Cd-O1 & 112.17 \\
\hline Sel-Hg-N2 & 118.69 & Sel-Cd-N2 & 116.85 & Sel-Hg-O1 & 89.99 & Sel-Cd-O1 & 96.81 \\
\hline Se2-Hg-N1 & 112.60 & Se2-Cd-N1 & 113.30 & Se2-Hg-N1 & 100.81 & Se2-Cd-N1 & 103.86 \\
\hline
\end{tabular}

TABLE 9: Antibacterial activities of $\left[\mathrm{LM}(\mathrm{SeCN})_{2}\right]$ complexes.

\begin{tabular}{lcccc}
\hline Microorganisms & \multicolumn{3}{c}{$\begin{array}{c}\text { Zone of inhibition }(\mathrm{mm}) \\
(\mathrm{His}) \mathrm{Cd}(\mathrm{SeCN})_{2}\end{array}$} \\
\hline E. coli & - & $\mathrm{Cd}(\mathrm{SeCN})_{2}$ & 35 & $(\mathrm{Gly}) \mathrm{Cd}(\mathrm{SeCN})_{2}$ \\
P. aeruginosa & 10 & 25 & 18 & 32 \\
S. typhi & 10 & 20 & 32 & 29 \\
S. aureus & 22 & 28 & 22 & 20 \\
K. pneumoniae & 22 & 20 & - & - \\
\hline${ }^{*}[15]$ & & - & &
\end{tabular}

* $[15]$

series. This is also clear from ${ }^{77}$ Se NMR data, which showed greater deshielding effect at the selenium via complexing to Histidine, which binds through two nitrogen atoms [32]. In general, good agreement of the experimental and theoretical IR starching bands observed for the prepared complexes with some blue shift of the calculated results because of the intermolecular interaction in the real IR experiment.

The CPMAS NMR spectral data for complexes (Gly)Cd(SeCN $)_{2}$ and (His) $\mathrm{Cd}(\mathrm{SeCN})_{2}$ for ${ }^{13} \mathrm{C}$ and $(\mathrm{Gly}) \mathrm{Hg}(\mathrm{SeCN})_{2}$ and (His) $\mathrm{Hg}(\mathrm{SeCN})_{2}$ for ${ }^{15} \mathrm{~N}$ are shown in Tables 5 and 6 , respectively. The solid-state ${ }^{13} \mathrm{C}$ and ${ }^{15} \mathrm{~N}$ NMR spectra are shown in Figures 1 and 2, and the peaks are denoted by asterisk. The calculated chemical shift tensors are also compiled in Tables 5 and 6, along with the span, $\Omega$, which describes the breadth of the chemical shift tensor and skew, $\kappa$, describing the shape of the powder pattern. From Table 5, solid-state ${ }^{13} \mathrm{C}$ NMR of Glycine and Histidine cadmium complexes shows increase in the chemical of the $\mathrm{Se}^{13} \mathrm{CN}$ NMR shift increased by $\sim 2 \mathrm{ppm}$ for mercury complex this is because the involvement of selenium in binding to the metal center, causing deshielding at the SeCN carbon. But in case of the ${ }^{15} \mathrm{~N}$ NMR data in Table 6, Histidine and Glycine complexes show a significant downfield shift of the nitrogen atom signal of the amines group; additionally, Histidine shows downfield shift for the imidazole moiety, which improves imidazole nitrogen involvement in binding to metal.

3.2. Computation Study. Computational study shows that Glycine $(\mathrm{C}=\mathrm{O})$ and $(\mathrm{C}-\mathrm{O})$ bonds in the optimized structure (Scheme 1) are shorter in $\mathrm{Cd}$ complex than that in $\mathrm{Hg}$ complex (Tables 7 and 8), which agree with experimental ${ }^{13} \mathrm{C}$ NMR results, while no differences in $(\mathrm{C}=\mathrm{O})$ and $(\mathrm{C}-$ $\mathrm{O})$ bonds were observed in His complexes indicating less contribution of carboxylate in binding. Se-Cd is shorter than $\mathrm{Se}-\mathrm{Hg}$ because of the size proximity in the sizes of $\mathrm{Se}$ and $\mathrm{Cd}$ atoms. It is worth mentioning here that the calculated bond lengths are comparable to reported experimental bond lengths for $\mathrm{Se}-\mathrm{Cd}$ obtained by single crystals (2.723 and $2.828 \AA$ ) $[20,21]$. It is also observed that $\mathrm{Hg}-\mathrm{N}$ and $\mathrm{Hg}-\mathrm{O}$ are longer than $\mathrm{Cd}-\mathrm{N}$ and $\mathrm{Cd}-\mathrm{O}$ because $\mathrm{Cd}$ is harder than $\mathrm{Hg}$, and this results in better interaction. This may cause higher stability of Cd complexes in general. Nitrogen is a less electronegative atom than oxygen, so it can donate electron more easily to the metal and form stronger bonds with metals, which results in stronger chelation through two nitrogens than chelation through nitrogen and oxygen. L-Histidine complexes of $\mathrm{Hg}$ and $\mathrm{Cd}$ have shorter bonds than Glycine complexes indicating stronger bonds in Histidine complexes, and this agrees with the higher electron donation concluded from ${ }^{77}$ Se NMR data.

3.3. Antibacterial Activity. The in vitro antibacterial activity studies were performed with Cd(II) complexes against activity of both gram-positive as well as gram-negative bacteria. Two complexes, (His) $\mathrm{Cd}(\mathrm{SeCN})_{2}$ and $(\mathrm{Gly}) \mathrm{Cd}(\mathrm{SeCN})_{2}$, exhibited their antibacterial activity compared to $\mathrm{Cd}(\mathrm{SeCN})_{2}$ except for K. pneumoniae which showed resistance to all the compounds tested, and $\mathrm{Hg}(\mathrm{SeCN})_{2}$ inhibition was reported previously [15], while mercury complexes with Glycine and Histidine did not show significant antibacterial activity. The activities of the complexes are summarized in Table 9. 


\section{Conclusions}

We have described the synthesis of $\mathrm{Cd}(\mathrm{II})$ and $\mathrm{Hg}$ (II) complexes of the type, $\left[(\mathrm{L}) \mathrm{M}(\mathrm{SeCN})_{2}\right]$ (where L=Histidine or Glycine and $\mathrm{M}=\mathrm{Cd}^{2+}$ or $\mathrm{Hg}^{2+}$ ), for use as a potential antibacterial agents. Characterization of these compounds by EA, IR solution, and solid NMR of various nucleuses reveals that the metal complexes with Histidine are more strongly coordinated than that of the corresponding Glycine containing metal complexes. The $\mathrm{Cd}(\mathrm{II})$ complexes have shown good zone inhibition towards different microorganisms, and thier further biological evaluation is under process, while no significant antibacterial activity was observed for the mercury complexes.

\section{Acknowledgment}

This parer was supported by the KFUPM Research Committee under project no. IN100039.

\section{References}

[1] F. R. Keene, J. A. Smith, and J. G. Collins, "Metal complexes as structure-selective binding agents for nucleic acids," Coordination Chemistry Reviews, vol. 253, no. 15-16, pp. 2021-2035, 2009.

[2] J. A. Drewry and P. T. Gunning, "Recent advances in biosensory and medicinal therapeutic applications of zinc(II) and copper(II) coordination complexes," Coordination Chemistry Reviews, vol. 255, no. 3-4, pp. 459-472, 2011.

[3] T. Marino, N. Russo, and M. Toscano, "Potential energy surfaces for the gas-phase interaction between $\alpha$-alanine and alkali metal ions $\left(\mathrm{Li}^{+}, \mathrm{Na}^{+}, \mathrm{K}^{+}\right)$. A density functional study," Inorganic Chemistry, vol. 40, no. 25, pp. 6439-6443, 2001.

[4] C. Orvig and M. J. Abrams, "Medicinal inorganic chemistry: introduction," Chemical Reviews, vol. 99, no. 9, pp. 2201-2204, 1999.

[5] Z. Guo and P. J. Sadler, "Medicinal inorganic chemistry," Advances in Inorganic Chemistry, vol. 49, pp. 183-306, 1999.

[6] P. C. Bruijnincx and P. J. Sadler, "New trends for metal complexes with anticancer activity," Current Opinion in Chemical Biology, vol. 12, no. 2, pp. 197-206, 2008.

[7] M. Peschke, A. T. Blades, and P. Kebarle, "Metalloion-ligand binding energies and biological function of metalloenzymes such as carbonic anhydrase. A study based on ab initio calculations and experimental ion-ligand equilibria in the gas phase," Journal of the American Chemical Society, vol. 122, no. 7, pp. 1492-1505, 2000.

[8] T. Marino, N. Russo, and M. Toscano, "Gas-phase metal ion $\left(\mathrm{Li}^{+}, \mathrm{Na}^{+}, \mathrm{Cu}^{+}\right)$affinities of glycine and alanine," Journal of Inorganic Biochemistry, vol. 79, no. 1-4, pp. 179-185, 2000.

[9] T. Marino, M. Toscano, N. Russo, and A. Grannd, "Structural and electronic characterization of the complexes obtained by the interaction between bare and hydrated first-row transitionmetal ions $\left(\mathrm{Mn}^{2+}, \mathrm{Fe}^{2+}, \mathrm{Co}^{2+}, \mathrm{Ni}^{2+}, \mathrm{Cu}^{2+}, \mathrm{Zn}^{2+}\right)$ and glycine," The Journal of Physical Chemistry B, vol. 110, no. 48, pp. 2466624673, 2006.

[10] H. Ai, Y. Bu, and K. Han, "Glycine- $\mathrm{Zn}^{+} / \mathrm{Zn}^{2+}$ and their hydrates: on the number of water molecules necessary to stabilize the switterionic glycine- $\mathrm{Zn}^{+} / \mathrm{Zn}^{2+}$ over the nonzwitterionic ones," Journal of Chemical Physics, vol. 118, no. 24, p. 10973, 2003.
[11] H. Pesonen, A. Sillanpaä, R. Aksela, and K. Laasonen, "Density functional complexation study of metal ions with poly(carboxylic acid) ligands-part 1: poly(acrylic acid) and poly $(\alpha$-hydroxy acrylic acid)," Polymer, vol. 46, no. 26, pp. 12641-12652, 2005.

[12] K. Hasegawa, T. Ono, and T. Noguchi, "Ab initio density functional theory calculations and vibrational analysis of zincbound 4-methylimidazole as a model of a histidine ligand in metalloenzymes," Journal of Physical Chemistry A, vol. 106, no. 14, pp. 3377-3390, 2002.

[13] J. A. Leary, Z. Zhou, S. A. Ogden, and T. D. Williams, "Investigations of gas-phase lithium-peptide adducts: tandem. mass spectrometry and semiempirical studies," Journal of the American Society for Mass Spectrometry, vol. 1, no. 6, pp. 473480, 1990.

[14] S. L. Li, J. Y. Wu, Y. P. Tian et al., "Design, crystal growth, characterization, and second-order nonlinear optical properties of two new three-dimensional coordination polymers containing selenocyanate ligands," European Journal of Inorganic Chemistry, no. 14, pp. 2900-2907, 2006.

[15] M. Nasiruzzaman Shaikh, B. A. Al-Maythalony, M. I. M. Wazeer, and A. A. Isab, "Complexations of 2-thiouracil and 2,4dithiouracil with $\mathrm{Cd}(\mathrm{SeCN})_{2}$ and $\mathrm{Hg}(\mathrm{SeCN})_{2}$ : NMR and antibacterial activity studies," Spectroscopy, vol. 25, no. 3-4, pp. 187195, 2011.

[16] P. Barraud, M. Schubert, and F. H. T. Allain, "A strong ${ }^{13} \mathrm{C}$ chemical shift signature provides the coordination mode of histidines in zinc-binding proteins," Journal of Biomolecular NMR, vol. 53, no. 2, pp. 93-101, 2012.

[17] M. I. M. Wazeer, A. A. Isab, and M. Fettouhi, "New cadmium chloride complexes with imidazolidine-2-thione and its derivatives: X-ray structures, solid state and solution NMR and antimicrobial activity studies," Polyhedron, vol. 26, no. 8, pp. 1725-1730, 2007.

[18] J. Boeckmann, T. Reinert, and C. Näther, "Investigations on the thermal reactivity of $\mathrm{Zn}^{\mathrm{II}}$ and $\mathrm{Cd}^{\mathrm{II}}$ selenocyanato coordination compounds," Zeitschrift für Anorganische und Allgemeine Chemie, vol. 637, no. 7-8, pp. 940-946, 2011.

[19] S. N. Shukla, P. Gaur, S. Mathews, S. Khan, and A. Srivastava, "Synthesis, characterization, catalytic and biological activity of some bimetallic selenocyanate Lewis acid derivatives of $N, \mathrm{~N}^{\prime}$ - bis (2-chlorobenzylidene)ethylenediamine," Journal of Coordination Chemistry, vol. 61, no. 24, pp. 3913-3921, 2008.

[20] S. Sain, T. K. Maji, G. Mostafa, T. H. Lu, M. Y. Chiang, and N. R. Chaudhuri, "Self assembly towards the construction of molecular ladder and rectangular grid of cadmium(II)selenocyanate," Polyhedron, vol. 21, no. 22, pp. 2293-2299, 2002.

[21] T. K. Maji, S. Sain, G. Mostafa, D. Das, T. H. Lu, and N. R. Chaudhuri, "Synthesis and crystal structure of selenocyanato bridged two dimensional supramolecular coordination compounds of cadmium(II)," Journal of the Chemical Society, Dalton Transactions, no. 21, pp. 3149-3153, 2001.

[22] A. A. Isab and M. I. M. Wazeer, "Complexation of $\mathrm{Zn}(\mathrm{II})$, $\mathrm{Cd}(\mathrm{II})$ and $\mathrm{Hg}(\mathrm{II})$ with thiourea and selenourea: $\mathrm{a}^{1} \mathrm{H},{ }^{13} \mathrm{C},{ }^{15} \mathrm{~N}$, ${ }^{77} \mathrm{Se}$ and ${ }^{113} \mathrm{Cd}$ solution and solid-state NMR study," Journal of Coordination Chemistry, vol. 58, no. 6, pp. 529-537, 2005.

[23] S. Hayashi and K. Hayamizu, "Chemical shift standards in high-resolution solid-state NMR (2) ${ }^{15} \mathrm{~N}$ nuclei," Bulletin of the Chemical Society of Japan, vol. 64, no. 2, pp. 688-690, 1991.

[24] W. Kemp, NMR in Chemistry, Macmillan Education Ltd., London, UK, 1986. 
[25] K. Eichele and R. E. Wasylischen, W: Simulation Package, Version 1. 4. 4, Dalhousie University, Halifax, Canada; University of Tubingen, Tübingen, Germany, 2001.

[26] M. J. Colaneri and J. Peisach, "A single crystal EPR and ESEEM analysis of $\mathrm{Cu}(\mathrm{II})$-doped bis(L-histidinato)cadmium dihydrate," Journal of the American Chemical Society, vol. 117, no. 23, pp. 6308-6315, 1995.

[27] N. U. Zhanpeisov, M. Matsuoka, H. Yamashita, and M. Anpo, "Cluster quantum chemical ab initio study on the interaction of NO molecules with highly dispersed titanium oxides incorporated into silicalite and zeolites," Journal of Physical Chemistry B, vol. 102, no. 35, pp. 6915-6920, 1998.

[28] A. Nicklass, M. Dolg, H. Stoll, and H. Preuss, "Ab initio energyadjusted pseudopotentials for the noble gases Ne through Xe: calculation of atomic dipole and quadrupole polarizabilities," The Journal of Chemical Physics, vol. 102, no. 22, pp. 8942-8952, 1995.

[29] M. Frisch, G. Trucks, H. Schlegel et al., Gaussian 09, Rev. A. 1, Gaussian Inc., Wallingford, Conn, USA, 2009.

[30] V. Navarro, M. L. Villarreal, G. Rojas, and X. Lozoya, "Antimicrobial evaluation of some plants used in Mexican traditional medicine for the treatment of infectious diseases," Journal of Ethnopharmacology, vol. 53, no. 3, pp. 143-147, 1996.

[31] P. Brooks and N. Davidson, "Mercury (II) complexes of imidazole and histidine," Journal of the American Chemical Society, vol. 82, no. 9, pp. 2118-2123, 1960.

[32] A. Renuka, K. Shakuntala, and P. C. Srinivasan, IndianJournal of Chemistry, vol. 37A, p. 5, 1998. 

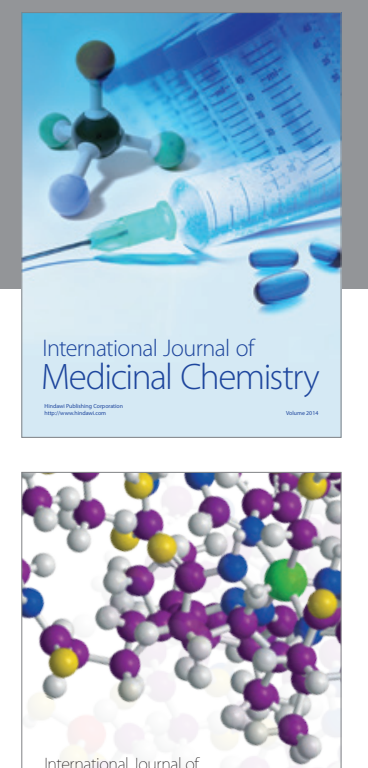

\section{Carbohydrate} Chemistry

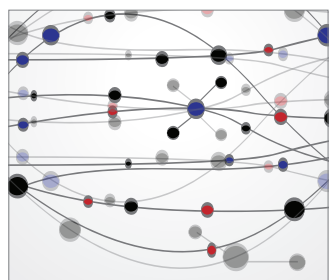

The Scientific World Journal
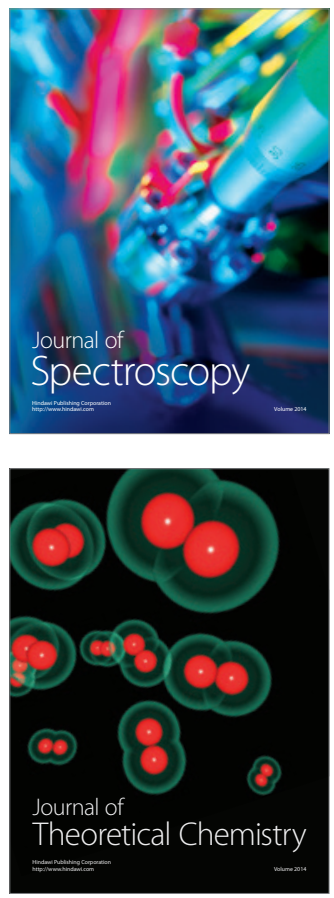
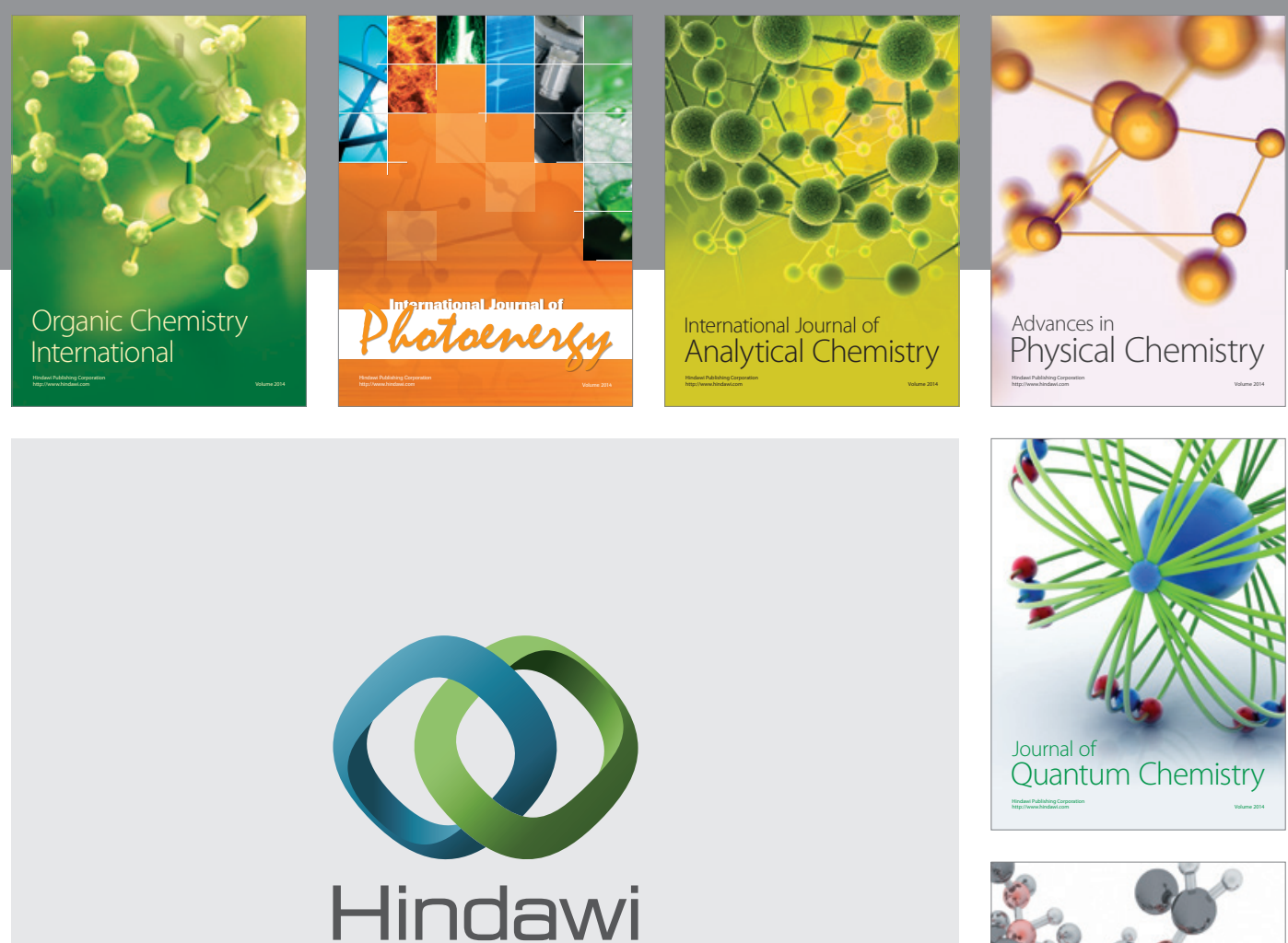

Submit your manuscripts at

http://www.hindawi.com

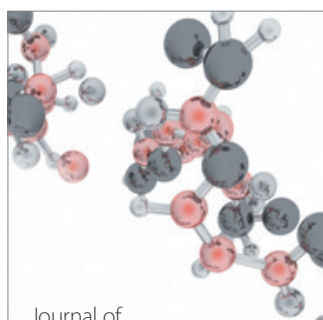

Analytical Methods

in Chemistry

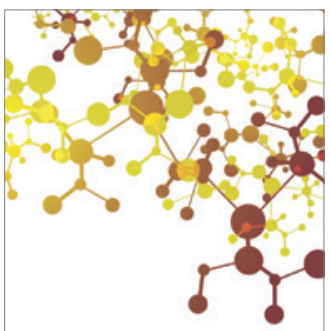

Journal of

Applied Chemistry

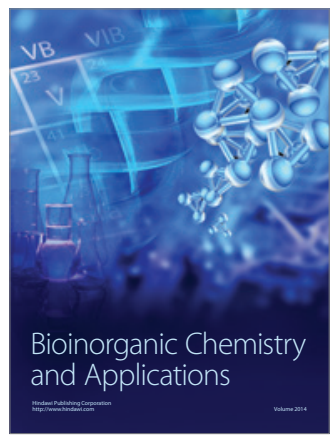

Inorganic Chemistry
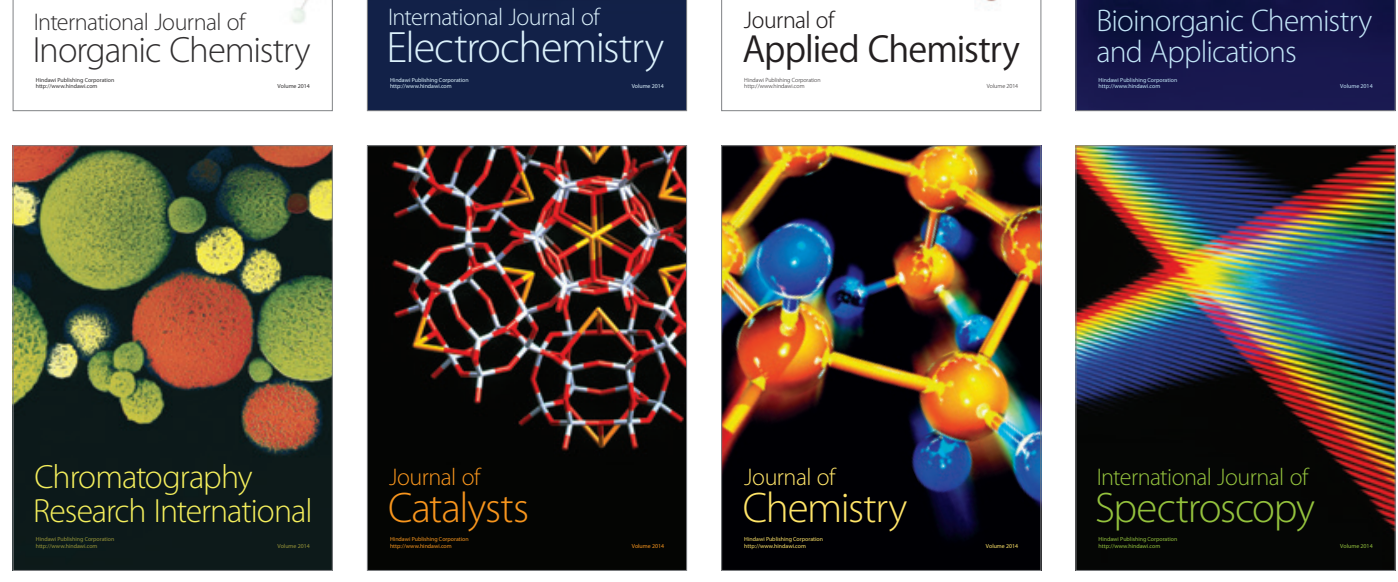